\title{
Xunzis ritualanalyse
}

\author{
KLAUS BO NIELSEN
}

\section{En over 2000 år gammel teori om ritualernes praksis}

\begin{abstract}
This article explores an ancient Chinese philosopher in conversation with modern sociological understanding of religion. The theorist of ritual to whom I will devote my attention here is the Chinese author Xun Kuang or Xunzi (310-230 B.C.). In his treatise on ritual ( $\mathrm{Li}$ Lun) he goes far beyond merely describing ritual performance, engaging in discourses presuming a kind of cognitive distance from its objects. In my discussion of Xunzi I will briefly note a few analogies, such as Durkheim, Radcliff-Brown, Rappaport etc. who seem in some respect to theorize in similar ways and for similar purposes. However the focus of this article is a discussion of Xunzi as a theorist of ritual practice and the distinct ways he shows a ritual theory that grounds itself on a sociological basis. In this light I claim that Xunzi's theory deserves to be taken seriously.
\end{abstract}

RESUME: Denne artikel undersøger en oldkinesisk filosofs syn på ritualernes praksis $i$ samspil med moderne sociologiske forståelser af religion. Den ritualteoretiker, jeg her vil beskxftige mig med, er den kinesiske forfatter Xunzi eller Xun Kuang (310-230 $f$. Kr.). I hans afhandling om ritualer (Li Lun) går han videre end blot at beskrive den rituelle akt, og anlægger en mere distanceret indstilling til ritualet og skitserer dermed en sociologisk baseret ritualteori, som har lighedspunkter med klassiske positioner som Durkheim, Radcliff-Brown og Rappaport. Det er i dette lys, at Xunzis ritualteori fortjener at blive taget alvorligt.

KEYWORDS: Xunzi, ritual, Confucianism, sociology, secularity, moral, emotions 


\begin{abstract}
Xunzi
Før samlingen af Kina i kejserriget under Qin-dynastiet i 221 f.Kr., som bragte den klassiske periode i kinesisk filosofi til ophør, ${ }^{1}$ havde kongfuzianismen en bemærkelsesværdig eksponent, Xunzi (310-230 f. Kr.). Hans værk, der som titel bærer hans navn, Xunzi, repræsenterer måske den mest sofistikerede udvikling af den kongfuzianske skole i De Stridende Staters Periode (403-221 f. Kr.). Medens Kong Fuzis og Mengzis synspunkter kun er bevaret i abrupte sekvenser, er Xunzis tanker anderledes stramt komponeret i essays, der indeholder underbyggede diskussioner af forskellige enkeltstående temaer, som tilsammen former et imponerende kohærent system af argumenter. Xunzi er af flere grunde blevet betragtet som repræsentant for den rationalistiske fløj i den tidlige kongfuzianisme - mest af alt fordi Xunzi benægter en intentionel, ekstrahuman indflydelse på det menneskelige liv, og i stedet opfatter mennesket som et autonomt væsen. I tråd med dette opererer Xunzi med en tanke om den ideelle relation mellem individet og dets sociale miljø, der er fundamental for forståelsen af en given traditions etiske livssyn. Det er også i dette regi, at Xunzi belyser sin teori om ritualernes funktion. Det er almindeligt anerkendt blandt forskere, at ritualer (li) er Xunzis vigtigste anliggende. Men hvad der er mindre anerkendt, er Xunzis relevans i forhold til nyere ritualforskning. Det er hensigten her at vise, at Xunzis indsigter om ritualernes form og funktion ikke er så fjernt fra de idéer, vi møder fx hos Émile Durkheim, Alfred Radcliffe-Brown, Erwin Goffmann og nyere socialt orienterede teoridannelser om ritualer (fx Roy Rappaport og Randall Collins). En af de få religionsforskere, som overhovedet har set et perspektiv i forhold til Xunzis ritualteori og moderne ritualstudier, er Catherine Bell. Hun skriver i indledningen til sin bog, Ritual: Perspectives and Dimensions, at hun har fulgt følgende devise fra Xunzi:
\end{abstract}

The ancient Chinese sage Xunzi quoted in the epigraph offers three pieces of practical advice for anyone attempting to talk about ritual. In effect, he warns against the temptation to reduce this complex phenomenon to simplistic formulas or strict categories. He also suggests that the elaborate theories constructed by means of labyrinthine methodological considerations will only lead one away from reality. Finally, he reminds us that we will never understand ritual if we are apt to look down on what other people do and view their actions from a position of intellectual or observational superiority. While recognizing the self-serving significance of this argument for a major proponent of Confucian teachings, this is still valuable advice that I have tried to take very seriously (Bell 1997, xii). ${ }^{2}$

1 Om denne vitale periode i Kinas historie, se Nielsen 2003. For specifik fremstilling af filosoffen Xunzi, se ibid. 100-122.

2 Bell hentyder sandsynligvis til en passage i Xunzi, hvor Xunzi taler om hvilke standarder, der ikke må anvendes, fordi de repræsenterer eksterne positioner, som ikke begriber ritualets dybere mening (se Watson 1963, 94-5). 
Gennem dette citat ses en indikation af Xunzis interessante tilnærmelse til ritualer. Xunzi fortjener i den henseende opmærksomhed, mest af alt, fordi hans tanker om ritualer er et af de få eksempler, der viser en analyse af ritualer, som tager sit udspring i et kulturelt miljø, der i tid og rum er forskelligt fra et vestligt akademisk udgangspunkt.

\section{Ritualerne}

Det sammensatte tegn $l i$ (ritualer, etikette) består af to ideografiske komponenter, hvoraf man kan udlede, at tegnet $l i$ oprindelig har refereret til en ofring på et alter til ånderne eller forfædrene. ${ }^{3}$

I Xunzis værk findes der et stort kapitel, som udelukkende er viet til en diskussion af ritualer (Li lun). De ritualer, som havde Xunzis positive opmærksomhed, betegnes med begrebet $l i$, der oftest oversættes med ritualer, etikette, omgangsformer m.m. $L i$ må på sin vis siges at være kulturspecifikt, da termen i principiel forstand ikke dækker over alle former for religiøse ritualer, men kun de kvalitative, traditionsbundne Zhouritualer. Man kunne hævde, at Xunzis diskussion af ritualer udspringer af den ene af de modeller, som Jonathan Z. Smith har fremsat, nemlig den, at det drejer sig om et lukket, religiøst verdensbillede, hvormed der menes, at individer må stræbe efter at placere sig i en passende sammenhæng med resten af kosmos ved fuldt ud at integrere sociale roller og institutioner (Smith 1970, 459-60). ${ }^{4}$ Det betyder dog ikke, at Xunzi forsøger at etablere en bestemt typologi af ritualer, men at $l i$ faktisk kan anskues som ritualer i en bred betydning, der dækker alle former for ritualer, sekulære såvel som religiøse. ${ }^{5} \mathrm{Li}$ indbefatter derfor også alle de klassifikationer af ritualer, der i tidens løb i ritualforskningen er blevet hæftet på typer af ritualer. Det enorme område og virkefelt, som kommer til udtryk i begrebet $l i$, kan man få en ganske god ide om ved at læse det

3 Ifølge Benjamin Schwartz besidder $l i$ i virkeligheden kimen til den bredere betydning, det fik senere under kongfuzianismen, idet $l i$ nøje må sammenholdes med anekulten. Sociologisk signifikant er det, at anekultens religiøse orientering med hensyn til tilbedelse af forfædrene, ligger i det faktum, at den belyser slægtsgruppens paradigmatiske sociale orden (se Schwartz 1985, 22f). Tegnet $l i$ indgår også i moderne kinesisk sprogbrug, som en rodbetegnelse for ritualer, som i fx lipai (tilbede).

4 Den anden model kan betegnes som et åbent religiøst verdensbillede, hvor individer til tider stræber efter at bryde ud af eller gå bag om deres kulturs sociale roller og institutioner (se Smith 1970, 459f). Det må samtidig siges at være karakteristisk for den klassiske daoisme (Daode jing og Zhuangzi), der netop søger at bryde eller løse op for fikserede normer, sociale roller og institutioner. Smiths modeller må naturligvis ikke forveksles med Karl Poppers idé om det henholdsvis åbne og lukkede samfund. Popper mener, at der grundlæggende er tale om to slags samfund, hvor det åbne samfund fundamentalt set er rationalistisk, individualistisk og demokratisk, mens det lukkede samfund er stik modsat, idet det betegnes som irrationelt, diktatorisk og kollektivistisk.

5 Det vil sikkert være mere passende at placere Xunzis forståelse og teori af ritualer på linie med det opgør, der fandt sted i midten af 1970'erne inden for ritualforskningen. Dette betød, at ritualer ikke længere udelukkende kunne relateres til religion, men måtte studeres i en meget bredere kontekst. Om dette se Moore \& Meyerhoff 1977. 
store klassiske kongfuzianske værk Liji (Riternes Bog). Her står det klart, at li dækker alt fra bordmanerer til initiationsritualer. Vi kan derfor betragte $l i$ som et domæne, der favner bredt, og som definerer sig ud fra de samme sociale fremtrædelsesformer som bl.a. Goffman (1967), Langer (1979), Rothenbuhler (1998) og Collins (2004) har beskrevet. Set i dette perspektiv er $l i$ (ritualer) ordnede symbolske komponenter, der optræder i næsten alle sociale handlinger. Konsekvensen af dette bliver hos Xunzi, at $l i$ indtager en fuldstændig dominerende position i hans 'socialiseringsteori', fordi $l i$ ikke alene skønnes at være midlet til at opretholde og regulere samfundet, men i sig selv bliver et udtryk for (eller er) den performative side af den altafgørende moral.

Det særlige interessante er at Xunzi fremlægger en teoretisk betragtning over ritualernes oprindelse, funktion og symbolik. Hans teori er funderet i en social model, der understøtter kongfuzianismens altafgørende fokus på det 'sociale menneske'.

\section{Xunzis metode og teori}

Xunzis teori om ritualer må ses som et ekstrakt af et bidrag til en bredere diskussion af datidens religiøse og ideologiske problemstillinger. Herunder ligger der en særlig målsætning for Xunzi, der nødvendigvis involverer hans eget engagement $\mathrm{i}$ ritualerne og en promovering af ritualernes universelle gyldighed som et middel til at skabe den rette samfundsordning.

Men der er alligevel flere forhold, der gør sig gældende, og som foranlediger til en betegnelse af Xunzis syn på ritualer som en ritualteori, eller mere præcis en teori om ritualernes praksis. Først kunne man stille spørgsmålet, hvorfor det overhovedet var nødvendigt for Xunzi at fremføre en teoretisk model om ritualer? Et af svarene til dette kan være, at ritualernes oprindelse og formål til en vis grad var blevet glemt. Ritualerne bar mange reminiscenser fra en svunden arkaisk kultur; men i Xunzis levetid eksisterede andre og nye livsformer, der krævede en reevaluering af ritualerne, der befriede ritualerne fra tidligere tiders sociale, ideologiske og religiøse grundlag. I hvert fald blev ritualernes formål og betydning et af debatemnerne for flere forskellige ideologiske orienteringer, heriblandt opponenter til den kongfuzianske bevægelse, såsom moisterne og legalisterne. ${ }^{6}$ Man kan derfor formode, at Xunzi forsvarede traditionerne og dermed ritualerne gennem en nyfortolkning, der allerede var begyndt med Kong Fuzi, og at han ydermere fandt det nødvendigt at argumentere for ritualernes rationale ved hjælp af en filosofisk diskurs. Det var ikke muligt udelukkende at forstå ritualerne ud fra en selvrefererende ramme, fordi de ikke i sig selv giver en forklaring, men er indhyllet i en kompleks symbolik, der forbliver dunkel for den ikke-kyndige eller uind-

6 Moisterne og legalisterne er to af de mange filosofiske 'skoler' fra perioden 5.- 3. årh. f. Kr. Moisterne er kendt for deres utilitaristiske synspunkter og idéen om altruisme (jian ai), medens legalisterne udelukkende var fokuseret på at skabe et politisk system, med vægt på en standardiseret lov $(f a)$, der stod i statens tjeneste. Der er i denne periode ikke kendskab til organiserede religiøse samfund. 
viede. Xunzis metode bliver derfor en analyse af ritualerne, som nedbryder deres forløb i isolerede enkeltdele, for derigennem at belyse enkelte centrale aspekter i ritualerne. Resultatet bliver en teori om ritualer, der tilfører dem mening fra en anden vinkel, idet Xunzi fremstår som en iagttager, der klassificerer og analyserer, hvilket ikke alene fører til en deskriptiv analyse af ritualets forløb, men også antager karakter af en fortolkning. Han forsøger tilmed at vise, at ritualernes forløb generelt kan opdeles i tre faser: 1. en initial fase, der består i simpelhed (zho), dvs. det ukultiverede, rå og ubearbejdede fase; 2. en fase der indikerer fuldbyrdelse i form eller mønster (wen); 3. en afsluttende fase der er betegnet ved glæde og nydelse (le). Xunzi forsøger endvidere at kortlægge ritualernes struktur ved at klassificere momenter i en rite og lænke dem sammen med et tilsvarende moment $i$ en anden. Et andet aspekt af ritualernes strukturelle dynamik angår de forskellige emotionelle faser, som gennemløbes af ritualernes deltagere. Det vil sige, at særlige rituelle faser korresponderer (eller bør korrespondere) med successive emotionelle stadier i individernes sindsstemninger. Man kan tilmed se, at der i Xunzis fortolkning af ritualerne opereres med forskellige binære markører, hvormed han anskuer ritualernes principper. Fx liv/død, rå/kogt, begyndelse/slutning, ufuldendt/fuldendt, sorg/glæde. ${ }^{7}$ I den sammenhæng fremstår de binære positioner som elementer, der ved hjælp af ritualerne ledes sammen i en harmonisk ækvivalens. Den religiøse legitimation synes for Xunzi at være den, at ritualerne forklarer anomalier og abrupte hændelser i det menneskelige liv, således at de kan reintegreres i det større verdensbillede.

\section{Xunzi og den kongfuzianske fortolkning af ritualer (li)}

Den kinesiske opfattelse af ritualer har måske noget at byde på, når det gælder en universel diskussion af moralske spørgsmål. Kongfuzianerne gjorde moralske domme til en integreret del af det rituelle liv. De kan måske siges at gøre opmærksom på, at moralske problemer ikke nødvendigvis omhandler specifikke handlinger eller mål, men at de navnlig angår de rituelle betingelser, hvormed mennesket lever. Ritualerne skal ideelt set udtrykke en balance mellem form og princip (wenli), mellem deltagernes sindsstemninger og ritualernes praktiske brug. Xunzi hovedformål med ritualerne var at placere dem og bevare dem som et centrum for det menneskelige liv; et rum for værdier og æstetik. Det er tænkeligt, at den folkelige opfattelse af ritualerne ikke længere var en tilstrækkelig grund, hvorfra ritualerne kunne forsvares.

7 Skønt Xunzi ser ritualerne bestående af binære markører, skal man ikke forvente at kunne uddrage en analytisk metode, som det fx er tilfældet i Leví-Strauss' Le cru et le cuit (Det rå og det kogte), hvor de samme grundlæggende binære positioner danner baggrund for Lévi-Strauss' strukturalistiske antropologi. Det kan dog ikke benægtes, at Xunzis forståelse af ritualernes struktur og transformationseffekt hviler på selve forholdet og bevægelsen mellem natur og kultur: det rå og det forarbejdede. Således kan li hos Xunzi ses som et instrument, der transformerer den rå og usocialiserede natur i mennesket (xing) til et fuldt ud socialt og kulturelt væsen (junzi). 
Kong Fuzi og de efterfølgende kongfuzianere understregede og udviklede ideen om ritualer (li) som samfundets basis. På et performativt niveau betød ritualer traditionelle konventioner, stiliserede og meningsfulde attituder, der inkluderede deres bevægelser og sproglige korrekte udtryk. På det dybere niveau var det for Xunzi ensbetydende med, at ritualet udvikler og fuldfører den menneskelige biologiske arv. Ved hjælp af gestik, øjenkontakt, håndtryk og ærbødig respekt for det korrekte sprog i den rette sammenhæng mente man at opnå engagement, samarbejde og mulighed for konfliktløsning. I både familie- og samfundsforhold udgjorde $l i$ den kreative proces, der gjorde civiliserede handlinger mulige. Derfor kan $l i$ ses som det komplekse spil, der bandt folk sammen på en sofistikeret måde. $L i$ dækker et bredt spektrum, og indbefatter ritualer, konventioner, etikette, religiøse ceremonier, overgangsritualer og visse områder af etik. $L i$ er derfor de meningsfulde roller, relationer og institutioner, der befordrer kommunikationen og fostrer en følelse af fællesskab, idet de udgør den sociale grammatik, som forsyner ethvert individ i samfundet med en defineret plads i familien, samfundet og staten.

Traditionerne er det kendte domæne, hvori kollektivet etableres, og individet finder sin identitet i et samfundsmæssigt perspektiv. For Xunzi såvel som for de øvrige tidlige kongfuzianere bliver man et humant væsen, en human person, i kraft af sin deltagelse i samfundet. Ved fødslen, før vi indrulleres i kulturens favntag, er vi ikke forskellige fra andre levende skabninger. ${ }^{8}$ Hvis et menneske ikke er villig til at deltage i samfundet og indgå i en harmonisk relation med andre, betyder det ikke blot, at det er vanskeligere for samfundet at realisere sit potentiale, men også, at mennesket selv forbliver på et niveau, der kan sammenlignes med dyrenes. Det er altså ikke tilstrækkeligt at være et menneske som følge af sin biologiske status. Derimod må man udnytte sin kognitive, æstetiske og spirituelle kræfter i det samfund, man virker i, og på den måde hæve sig til en position, der adskiller mennesker fra den dyriske verden. Hvis man ikke kan tøjle sine passioner, instinkter og narcissistiske ønsker, som vi mennesker deler med dyrenes basale opretholdelsesdrifter, men i stedet tilkæmper vores egoistiske mål ved hjælp af vold eller brutal styrke, så er det, vi forfejler at blive sande mennesker og opnå en human verden. Biologisk set er mennesket ikke på forhånd udstyret med bestemte moralske kvalifikationer, men tilegner sig en given moral gennem samfundets og kulturens påvirkninger, dvs. igennem socialiseringsprocessen. For Xunzi afhænger statens evne til at fremelske fred og velfærd af den sociale ordens retfærdighed. Den rette orden er til stede, hvis man holder sig de initiale overvejelser for øje, der muliggør, at staten kan etableres, nemlig det forhold at den naturnødvendige ulighed mellem mennesker er til gavn for alle, i stedet for at de rige og magtfulde simpelthen udnytter de svage og fattige. Xunzi viede mange kræfter til diskussionen om opdelingen af arbejdet i et givent samfund, hvilket han ideelt set opfattede som et udtryk for et na-

8 Mengzis synspunkt var i kontrast til Xunzis teori, at mennesket er unikt, fordi det som eneste væsen besidder en medfødt moralsk sans; der blandt andet udmønter sig i medmenneskelighed (ren) og retsind (yi). For Mengzi var det den grundlæggende distinktion mellem mennesker og dyr. 
turligt hierarki. Dette socialutilitaristiske postulat betyder, at enhver afvigelse fra reglen om det fælles bedste, ikke alene resulterer i moralsk fordømmelse, men underminerer dets egen raison d'être, idet det handler om en forøgelse af velfærden på en ordentlig måde (se Roetz 1993, 68-70).

\section{Xunzis teori om ritualernes oprindelse}

Hvis vi på baggrund af det ovennævnte vil trænge mere til bunds i Xunzis teori om ritualernes oprindelse og funktion, må vi vende os mod den antropologi, hvormed han anskuer mennesket. Det viser sig nemlig, at $l i$ kan betragtes som et slags værn mod naturbetingede og ikke socialiserede kræfter i mennesket:

\footnotetext{
What is the origin of ritual? I reply: man is born with desires. If his desires are not satisfied for him, he cannot but seek some means to satisfy them himself. If there are no limits and degrees to his seeking, then he will inevitably fall to wrangling with other men. From wrangling comes disorder and from disorder comes exhaustion. The ancient kings hated such disorder, and therefore they established ritual principles in order to curb it, to train men's desires and provide for their satisfaction. They saw to it that desires did not overextend the means for their satisfaction, and material goods did not fall short of what was desired. Thus both desires and goods did not fall short of what was desired. Thus both desires and goods were looked after and satisfied. This is the origin of rites (Watson 1963, 61). ${ }^{9}$
}

Det er værd at lægge mærke til, at Xunzi legitimerer ritualernes sande værdi ved at tilskrive fortidens vise konger deres oprindelse. En stadfæstelse gennem en almen anerkendt autoritet, som de vise konger, var en manøvre, som langt fra er enestående for Xunzi, men som også kan iagttages hos flere af de øvrige filosofiske skoler i det gamle Kina. ${ }^{10}$ Men Xunzis egentlige argument for deres oprindelse viser sig endegyldigt at være grundet på en overvindelse af problemer forbundet med den menneskelige natur (xing). Ritualerne er ifølge Xunzi et middel til at kanalisere impulserne og drifterne således, at de afbalanceres med social agtværdighed. Hvis den menneskelige natur, i dens rå udfoldelse, ikke kultiveres og dermed ikke holdes i ave gennem et sæt af sociale principper, vil menneskeheden gå til grunde i grådighed og egoisme. Etik og moral manifesterer sig gennem ritualerne, der i sig selv er et produkt af menneskelig kultiveret og bevidst tænkning. I fald ritualerne ikke efterleves, vil strid dominere

9 Citatet er hentet fra Burton Watsons oversættelse af centrale kapitler i det oprindelige værk Xunzi. Watsons oversættelse må sammen med John Knoblocks oversættelse af hele værket Xunzi, siges at være de nuværende standardoversættelser (se litteraturliste).

10 For de kinesiske tænkere i perioden var fortidens gyldne tidsalder eller den historiske appel en generisk term, der konstituerede forskellige specifikationer af dens signifikans. Den historiske appel har i kongfuzianismen i høj grad en pædagogisk funktion (se fx Cua 2000, 41f). 
frem for harmoni. I princippet betyder dette, at ikke alle vil begære de samme ting på det samme tidspunkt, hvorved muligheden forøges, for at alle opnår en vis delagtighed $i$ at fuldføre de pligter og målsætninger, der gælder hvert enkelt individ. De tidlige kongfuzianere var eksplicitte med hensyn til at forstå samfundet (og li) som en menneskeskabt ordning og historien blev anset for intet mindre end menneskehedens tidligere anstrengelser for at komme i overensstemmelse med de livsbetingelser og den verden, de levede i. Der er imidlertid også en passus i Xunzi, der vil begrunde offerritualernes sociale funktion i ritualernes emotionelle baggrund hos og virkning på ritualdeltagerne. Xunzi siger:

The sacrificial rites originate in the emotions of remembrance and longing for the dead. Everyone is at times visited by sudden feelings of depression and melancholy longing. A loyal minister who has lost his lord or a filial son who has lost a parent, even when he is enjoying himself among congenial company, will be overcome by such feelings. If they come to him and he is greatly moved, but does nothing to give them expression, then his emotions of remembrance and longing will be frustrated and unfilled, and he will feel a sense of deficiency in his ritual behaviour (Watson 1963, 109)

Med henvisning til dette forklarer Xunzi, hvorfor det blev en nødvendig konsekvens at opsætte specifikke ritualer, der kunne kanalisere savnet og sorgen af de nærmeste efterladte på en sådan måde, at de får deres passende udtryk og ikke tager magten fra en. Men for Xunzi har den emotionelle længsel en videre betydning end individets sorgbearbejdelse, idet længsel og sorg også er et udtryk for de sociale bånd og respekten for medmennesker.

\section{Ritualer og følelser}

Den britiske antropolog, Radcliffe-Brown (1881-1955) offentliggjorde i sin berømte monografi om andamanerne, The Andaman Islanders, fra 1922 en tese om, at et velordnet socialt liv i det menneskelige samfund afhænger af tilstedeværelsen af særlige følelser i individernes bevidsthed, som kontrollerer individets adfærd i relation til de øvrige samfundsmedlemmer. Ritualerne kan i dette lys ses som regulerede symbolske udtryk for disse følelser. Radcliffe-Brown hævdede endvidere, at ritualerne har den specielle sociale funktion at regulere, opretholde og fra en genereration til en anden at videreføre de følelser, hvorpå selve konstitutionen af samfundet hviler (se RadcliffeBrown 1952, 157). I 'Henry Myers Lecture' i 1945, under titlen "Religion and Society" understøttede han, ganske overraskende, sin egen teori fra 1922 med reference og diskussion af Xunzis 'ritualteori', idet han erklærede, at hans egen tese på ingen måde var ny, eftersom den allerede kunne findes i Xunzis skrifter og det kongfuzianske værk, Liji (Riternes Bog). Radcliffe-Brown opfattede altså sin egen teori som grundlæggende identisk med den fortolkning, de tidlige kongfuzianere havde af ritualerne. I den sam- 
menhæng hæftede Radcliffe-Brown sig ved, at man ikke diskuterede et begreb som 'religion' i den kinesiske kontekst, men derimod $l i$, (ceremonier, ritualer og etikette). ${ }^{11}$ Som indledning til en længere diskussion af Xunzis opfattelse af ritualerne konkluderede Radcliffe-Brown (1952, 159), at det syn på religion, som han selv fremlagde, passende kunne defineres ud fra et citat fra Riternes Bog: "Ceremonies (li) are the bond that holds the multitudes together, and if the bond be removed, those multitudes fall into confusion". Den kongfuzianske opfattelse af $l i$ er utvetydig og eksplicit i sin fremhævelse af $l i$ som det sociale bånd og det, hvormed samfundet struktureres. Ganske overraskende inddrager Radcliffe-Brown i denne forbindelse et andet aspekt af $l i$, som han mener finder sit klareste udryk hos filosoffen Xunzi, og som endvidere understøtter Radcliffe-Browns universelle teori om, at ritualerne tjener til at regulere og kultivere menneskelige følelser. Men Radcliffe-Browns strukturelle funktionalisme fornægter sig ikke, fordi denne fokus på følelser har en social reference (i lighed med Xunzis teori), idet det er den samme regulering, opretholdelse og indflydelse fra disse følelser, der gør det muligt at skabe et velordnet socialt samfund. Når Radcliffe-Brown på denne måde fremhævede Xunzis ritualopfattelse, var det næppe blot for at påpege dens iboende kvaliteter, men også og mere for deri at finde en bekræftelse på hans egen teori.

Ifølge Xunzi har ritualerne deres egne rationelle formål. Visse ritualer, fx begravelsesritualerne, har en funktion, der i høj grad henvender sig til deltagerne; de kan igennem ritualet demonstrere taknemmelighed over for og kærlighed til de afdøde slægtninge. Der synes her at være mindre interesse for, om forfædrene reelt modtog ofringerne, i forhold til de korrekte emotionelle manifestationer, som ritualerne mentes at generere og transformere. I nyere tid har især Collins (2004) beskæftiget sig med den emotionelle energi, som han mener genereres af ritualer, og som han sammenfattende benævner collective effervescence. ${ }^{12}$ I lighed med Xunzi argumenterer Collins for, at ritualer forbinder og medierer gruppestrukturen og tros- og tankeforestillinger. Også for Collins spænder ritualer vidt, idet de viser sig såvel i helt almindelige samtaler som i stor skala, fx ved statslederbegravelser, der har det samme overordnede mål, nemlig at binde mennesker sammen.

Som det er tilfældet hos Durkheim, Goffman og Collins, er ritualet hos Xunzi den mekanisme, med hvilken de moralske sentimenter produceres og formes i specifikke sociale former. Konsekvensen er den, at den rituelle handling og dens interaktioner former det efterfølgende spektrum af adfærd, tanke og emotioner i individets deltagelse i ritualerne. Ritualet kan derfor siges at producere og reproducere moralske sentimenter i individet. Xunzi pointerer dette forhold eksplicit: "Ritual is the means by which

11 I hvilken grad termen 'religion' er ækvivalent med begrebet $l i$, uddybede Radcliff-Brown ikke. Han stødte her på den velkendte situation, at der ikke findes et eksakt tilsvarende begreb som 'religion' i det klassiske kinesiske originalsprog. Det vil dog være mere passende at fastholde den generiske betydning af $l i$ som dækkende et bredt spektrum af ritualer, både sekulære og verdslige.

12 I realiteten et udtryk overtaget fra Durkheim, der ofte i Formes élémentaires (1912) benyttede termen effervescens som betegnelse for kollektiv opstemthed, munterhed og 'beruselse'. 
to rectify yourself; the teacher is the means by which ritual is rectified" (Watson 1963, 30). Andetsteds siges det i Xunzi: "If you are stupidly sincere and ploddingly honest, temper your character with rites and music" (Watson 1963, 26), og yderligere hedder det: "Of all the ways to order the temperament and train the mind, none is more direct than to follow ritual" (Watson 1963, 2). Her drejer det sig ikke om kortvarige og forbigående former, men om ritualets dybere, kultiverende effekt, der hævdes at fremstille og konstituere et socialt og etisk ståsted. Som Susanne Langer udtrykker det:

\footnotetext{
Ritual 'expresses feelings' in the logical rather than the physiological sense. It may have what Aristotle called "cathartic value", but that is not the characteristic; it is primarily an articulation of feelings. The ultimate product of such articulation is not simple emotion, but a complex, permanent attitude ... A rite regularly performed is the constant reiteration of sentiments toward 'first and last things'; it is not a free expression of emotions, but a disciplined rehearsal of 'right attitudes (Langer 1979, 153).
}

$L i$ repræsenterer, som Rappaport har påpeget i forbindelse med ritualer generelt, en altomfattende, harmoniserende og forenende verdensorden, der på en gang er naturlig og moralsk, men som det påhviler mennesket at vedligeholde og genoprette i den rituelle handling (se Rappaport 1999, 365f). Social realitet er kernen i den moralske realitet. Samfundet holdes sammen ved hjælp af følelsesmæssige forestillinger om rigtigt og forkert: emotionelle sentimenter, der driver mennesker til bestemte handlinger, og foranlediger en 'retfærdig' modstand mod visse andre. Det står klart, at ritualer hos Xunzi opfattes som konventionelle former, der kommer til udtryk i de interaktioner, som består af sociale koder for opførsel. Der er ikke noget skel mellem religiøse og sekulære ritualer i den kongfuzianske kontekst, om end li oprindeligt kunne karakteriseres som offerhandlinger henvendt til ånderne eller forfædrene. I henseende til den kongfuzianske fortolkning af ritualerne omfatter eller transformerer ritualerne (li) sig logisk over i konventioner. ${ }^{13}$

\section{Ritualernes flerdimensionelle funktion}

Ifølge Xunzi kan ritualerne forstås på flere niveauer, og i den forstand kan de tjene et flerdimensionalt formål. Xunzi tilhørte eliten eller de lærde ( $r u$ jia), og han gjorde gentagne gange opmærksom på, at ritualerne indeholder en mere indirekte og dybere mening end blot den at være et redskab for at tjene ånderne.

Only a sage can fully understand ritual. The sage has a clear understanding of it, the gentleman finds comfort in practicing it, the official takes it as something to be preserved,

13 Denne konsekvens er pointeret af bl.a. Rappaport, hvor skridtet fra ritual til konvention er en logisk forlængelse (se Rappaport 1999, 24). 
and the common people accept it as custom. To the gentleman it is a way of being human (ren dao); to the common people it is a matter of serving the spirits (gui shi) (Watson 1963, $110)$.

I det ovennævnte citat introduceres et hierarki af forskellige måder, hvorpå betydningen af den rituelle akt bør forstås. For den, der forstår den 'reelle' natur i ritualerne, ses de, som det de essentielt er, nemlig vejen til at blive et 'menneske'. ${ }^{14}$ Det er dette perspektiv, Xunzi gentagne gange taler for, og som udgør grundstenen i hans sociale og politiske teori, hvor ritualerne er ledetråden til det harmoniske samfund. At se ritualerne som indirekte symbolske udtryk for en social dimension står ikke i et direkte modsætningsforhold til ritualets adressering henvendt til guder og forfædre. For dem, der ikke forstår ritualets sande betydning, hvilket primært vil sige det almindelige folk, som indtager en lavere position i hierarkiet, og hvis sociale rolle er anderledes end den uddannede elite, drejer ritualerne sig først og fremmest om at tjene ånderne. Selv om Xunzi argumenterer for et alternativ syn på ritualerne og deres betydning for dannelsesprocessen og samfundets ideelle strukturering, accepterer han alligevel forskellige niveauer i opfattelsen af ritualerne. Set på denne måde har hvert af disse niveauer for indgangen til ritualerne deres funktion og berettigelse. I spændvidden fra at betragte ritualerne som vejen til at blive et menneske til forståelsen af dem som betydningsfulde traditioner til deres funktion om at tjene ånderne skabes en åbning, hvor et hierarki af deltagelsesniveauer finder plads for deres udfoldelse. Ritualet bliver derfor et domæne, hvor alle deltager på forskellige måder i henhold til forskellige sociale niveauer. Ritualerne kan betragtes som en aktivitet, hvor alle samfundets medlemmer involveres. Der er kun forskelle i deltagernes respektive forståelse af ritualerne. Xunzi synes at indrømme, at hans teori om ritualerne ikke er (og kan ikke være) indlysende for alle; der vil altid være nogen, der anskuer ritualerne på en delvis og begrænset facon, som er mindre end det ideelle eller ultimative, men ikke i sig selv kan ses som en ukorrekt forståelse af ritualerne. Xunzi afviser dog at tillægge ritualerne en direkte instrumentel karakter, der sigter på en manipulation (i form af magi) af 'overnaturlige' kræfter:

You pray for rain and it rains. Why? For no particular reason, I say. It is just as though you had not prayed for rain and it rains anyway. The sun and moon undergo an eclipse and you try to save them; a drought occurs and you pray for rain; you consult the arts of divination before making a decision on some important manner. But it is not as though you could hope to accomplish anything by such ceremonies. They are done merely for ornament (wen). Hence the gentleman regards them as ornaments, but the common peo-

14 Her er det vigtigt at holde sig for øje, at moral og etik for Xunzi er et produkt af kulturens former og den bevidste tænkning (se Watson 1963,157) Et synspunkt der står i modsætning til en opfattelse som den, der var udtrykt af Mengzi (370-290 f. Kr.). If. denne udsprang moralen af den menneskelige natur i form af sociale instinkter, men disse var i sig selv blot spirer, der kræver pleje, for at den menneskelige moralske natur kan modnes og stabiliseres (se Lau 1970, 160. 164). 
ple regard them as supernatural. He who considers them ornaments is fortunate; he who considers them supernatural is unfortunate (Watson 1963, 85).

Legitimeringen af ritualerne hviler ikke på en metafysisk eller guddommelig basis. Deres værdi består derimod i deres evne til at generere kulturelle værdier. Den demytologiserede natur bliver i ritualet et kalkulerbart objekt for en menneskelig praksis. Verden og dens fænomener får sin skabte eksistens af naturen; men det er i kraft af menneskets evner og bevidste intentioner (wei), at det menneskelige samfund bliver bragt til orden. Hvis vi skal sidestille Xunzis teori om ritualer ud fra to af de mest verserende funktionsbestemmelser af religion, nemlig integrations- og interpretationsteorien, så må Xunzis teori om ritualernes funktion primært forstås som eksempel på en integrationsteori. I betragtning af, at Xunzi forsvarer ritualerne som samfundsstrukturerende er dette næppe overraskende; men det er også i den forbindelse, at Xunzis positive fremhævelse af ritualernes universelle gyldighed bliver en positionering, der opererer ud fra en bestemt ideologi, og derfor ikke har, i lighed med et moderne forskningsideal, en tilskyndelse til den størst mulige og nøgterne objektivitet. For Xunzi er den socialt konstruerede realitet samtidig den 'virkelige' realitet.

\section{Ritualer og social struktur}

Efter en sondering over ritualernes gennemgribende indflydelse på det sociale liv fastslår Roy Rappaport: "I therefore take ritual to be the social act basic to humanity" (Rappaport 1993, 31). Man kan med hensyn til ritualer placere kongfuzianismens opfattelse af dem på linie med Rappaport. Det står klart, at kongfuzianerne gang på gang påpegede, at mennesket er et socialt væsen. Den kongfuzianske vision om social orden inkluderer et sæt af klart adskilte sociale positioner med tilhørende eksplicitte pligter. Disse positioner former et hierarki baseret på forskellige distinktioner. Ritualer kan ses som religiøse i durkheimsk forstand, idet deres funktion er at integrere individerne i et givent samfund, og samtidig bidrager til dette samfunds moralske samstemmighed.

Det mest markante i Xunzis forklaring på ritualernes funktion er, at de i lighed med socialvidenskabelige ritualteorier relaterer ritualerne til samfundets struktur. Og man kunne ydermere hævde i lighed med Edmund Leach og Émile Durkheim, at ritualernes socialt refererende struktur er ideel snarere end reel (se Leach 1970, 15). Xunzi siger:

The Son of Heaven alone performs the suburban sacrifice to Heaven; altars of the soil may not be established by anyone lower than a feudal lord; but sacrifices such as $t^{\prime}$ an may be carried out by the officials and high ministers as well. In this way rites distinguish and make clear that the exalted should serve the exalted and the humble serve the humble, the great corresponds to great and small to small (Watson 1963,91). 
For Xunzi tjener ritualerne til at opretholde de sociale distinktioner, medens de samtidig skaber og vedligeholder den sociale harmoni. I en analyse af libertionsofferet (xiang), ${ }^{15}$ søger Xunzi at vise, hvordan ritualerne udstiller de principper, på hvilke samfundet hviler, og derved konstituerer samfundet som en kohærent gruppe af individer. Denne socialt strukturerende funktion ses også i ritualernes mere dagligdags og ordinære forhold, eksempelvis omkring den etikette og formalisering, der findes ved indtagelse af måltiderne i familien, ligesom alle ofringer af mad efterfølgende konsumeres af deltagerne i den rækkefølge, der svarer til deres positioner i det samfundsmæssige hierarki. ${ }^{16}$ Xunzi giver ritualerne en social og kulturel karakterisering. Deres værdi består i deres metaforiske anvisning for det menneskelige liv og samfund, hvor samtidig en afvigelse fra eller en udelukkelse af disse uundgåeligt fører til, at man mister sit ståsted og orientering i verden, som i sidste instans kan resultere i et samfundsmæssigt kaos. Xunzi siger:

\footnotetext{
Men, once born, must organize themselves into a society. But if they form a society without hierarchical divisions, then there will be quarrelling. Where there is quarrelling, there will be chaos; where there is chaos, there will be fragmentation; and where there is fragmentation, men will find themselves too weak to conquer other beings. Thus they will be unable to dwell in security in their houses and halls. This is why I say that ritual principles must not be neglected even for a moment (Watson 1963, 46).
}

For kongfuzianerne er et velordnet samfund et hierarkisk samfund, som Xunzi flere gange slår fast. Det er derfor den hierarkiske struktur, der udgør skelettet i samfundsopbygningen. Ritualer og institutioner må videreføres fra generation til generation, der i første omgang er sat op for at minde os om det pågældende samfunds særlige ontologi og fortolkningsskemaer. Samfundet må konstant indgydes med den nødvendighed, det er at knytte sig til de basiselementer, der eksisterer i den sociale verden, og som ydermere betinger et samfunds overlevelse.

Man bør her notere sig den pointering, der gang på gang forekommer i kongfuzianismens forståelse af den rituelle offerhandling, nemlig at man bør ofre, som om ånderne er til stede. Det forhold, at ritualerne i den kongfuzianske kontekst spiller på en som om-fiktion, udtrykkes adskillelige steder i den tidlige kongfuzianske litteratur og kommer til at stå i opposition til ritualernes oprindelige (og folkelige) dedikation til guder og ånder. Kongfuzianismen har aldrig afvist de traditionelle ritualer, men har derimod forsøgt at transformere dem til en kultiveret etikette, der udtrykker den autentiske, kinesiske livsform. På dette punkt er der en bemærkelsesværdig retorisk symmetri med sociologen Peter Berger. I lighed med Xunzi udvikler Peter Berger en teoretisk ramme til forståelse af, hvorfor mennesker skaber samfund og hvordan de bygger institutioner, ritualer og andre mekanismer med det formål at bevare den sociale

15 Om xiang-ceremonien, se endvidere Legge 1967, 1, 435-45.

16 Se et eksempel på dette i ritualbeskrivelsen i værket Liji (Legge 1967, 2, 210-20). 
orden. Samfundet er derfor hos Berger udelukkende et produkt af bevidst menneskelig aktivitet, hvilket Xunzi vil kalde wei (bevidst aktivitet). Religiøs legitimitet eller teodicé fungerer ifølge Berger på den måde, at de forklarer og integrerer de aspekter af det menneskelige liv, som truer fortsættelsen af den eksisterende sociale orden. ${ }^{17} \mathrm{Et}$ særkende ved den menneskelige art er ifølge Xunzi, at den i modsætningen til visse dyrearter, der også former samfund, har en særlig evne til at organisere sig i sociale strukturer og udnytte de givne ressourcer (se Watson 1963, 45f). På den anden side fødes mennesker allerede ind i sociale organisationer, i hvilken individets identitet tager form. På den måde er samfundet altid før individet.

\section{Ritualernes metaforiske karakter}

Xunzi er opmærksom på, at særlige rituelle handlinger ikke altid 'betyder', hvad de ser ud til at betyde. De anvendes ofte på en indirekte måde til at referere til noget, der ikke er umiddelbart tydeligt. For Xunzi befinder ritualer sig i et domæne, der beherskes af imitationer og symboler (xiang). ${ }^{18}$ Xunzi siger i overensstemmelse med hans opfattelse af de rituelle objekters metaforiske karakter: "Ritual uses material goods for its performance, follows the distinctions of eminent and humble in creating its forms, varies in quantities in accordance with differences of station and varies its degree of lavishness in accordance with what is appropriate" (Watson 1963, 96). I Xunzis forklaring af symbolerne i begravelsesritualerne vil man lægge mærke til, at det er igennem den metaforiske karakter, at to tilsyneladende uforenelige realiteter forenes. Xunzi siger:

In the funeral rites, one adorns the dead as though they were still alive, and sends them to the grave with forms symbolic of life. They are treated as though dead, and yet as though still alive, as though gone, and yet as though still present. Beginning and end are thereby unified (Watson 1963, 103).

Gennem denne sammenføring af to binære poler reintegreres den afdøde i et større verdensbillede og harmonien generhverves.

17 I modsætning til Berger trækker Xunzi i sin 'ritualteori' en forbindelse til den usocialiserede natur hos mennesket. For et komparativt studie af Berger og Xunzi, se Kline 2001. Xunzis opfattelse af socialiseringsprocessen er forskellig fra Bergers. For Berger såvel som Xunzi er det socialiseringen, der gør én til et menneskeligt væsen, men Berger ser denne proces som udgået fra ex nihilo (Berger 1967, 33). Det nyfødte menneskebarn er en tabula rasa, der venter på aftrykket fra dets samfund. For Xunzi er socialiseringen en transformationsproces, idet den dæmper og transformerer de naturlige drivkræfter og dispositioner (som mennesket allerede besidder fra fødslen), sådan at individets adfærdsmønster tilpasses den sociale orden. Derfor kommer, i henhold til Xunzi, alle mennesker til verden med et komplekst kognitivt og sensorisk apparat, der er forberedt til at tolke omverdenen og fungere i forhold til denne.

18 Tegnet eller termen 'xiang' som anvendes hos Xunzi, oversættes normalt som 'billede' eller 'symbol'. 
Den kongfuzianske forståelse af ritualer implicerer et sæt af paradigmatiske relationer, i hvilke individer interagerer med hinanden. Disse interaktioner udgør kulturens fundamentale træk og fastholder kognitive systemer. Det essentielle for Xunzi er netop, at ritualerne udtrykker konkrete, kulturelle mønstre såsom hierarkiske orienteringer og funktionelle relationer i det menneskelige samfund. I den forstand forstår Xunzi ritualerne som symbolske handlingssystemer, der i deres metaforiske karakter repræsenterer et større hele. Lakoff og Johnson har argumenteret for, at basale kulturelle metaforer delvist er bevaret og er propaganderet ved hjælp af ritualer (se Lakoff \& Johnson 1980, 234). Dette må i høj grad siges at være tilfældet i den kongfuzianske ritualpraksis, der eksponerer den autentiske kinesiske livsform og dens værdier. Zhouritualerne har en metaforisk karakter. De var designet til at indskærpe og repræsentere noget større, for så vidt som de udtrykte et harmonisk fællesskab med himlen og alle sociale institutioner. Men Xunzi tolkede, som ingen anden kongfuzianer før ham, ritualerne næsten udelukkende som sociale manifestationer og kultiverende redskaber.

\section{Konklusion}

Jeg har prøvet at vise hvordan Xunzi konstruerer en ritualteori, der involverer en særlig måde at forklare ritualer på, der kan sammenlignes med en forskers undersøgelse af sit objekt. Han beskæftiger sig i sin analyse af ritualer overordnet med deres oprindelse, form og funktion, der åbner op for en vinkel, hvorunder ritualerne kan ses som en måde 'at blive menneske på'. Han opponerer mod, hvad der i hans øjne kan betegnes som en naiv opfattelse, nemlig den at ritualer (kun) angår forholdet til en ekstrahuman verden $\mathrm{i}$ form af ånder eller guddommelige væsener. Ritualerne tjener primært til at lede og transformere emotioner og begær i den menneskelige natur samt skabe struktur og sammenhæng i det menneskelige samfund. Det vil på basis af Xunzis diskussion om ritualer ligeledes være rimeligt at konkludere, at han forskyder ritualets adresse fra den guddommelige til den menneskelige sfære. Han afviser værdien af eller effektiviteten i magi, fordi der for Xunzi ikke reelt er nogen guddommelige magter, der engagerer sig i menneskets tilværelse. Xunzis teorier, hvad enten de omhandler ritualer, politik eller epistemologi, har en pragmatisk målsætning og må som sådan vurderes ud fra en performativ synsvinkel, der kan afklare teoriernes værdi i praksis. Xunzi fremsætter et enkelt sted en definition på, hvad en teori bør være: "Hence if a man sit on his mat propounding some theory, he should be able to stand right up and put it into practice, and show that it can be extended over a wide area with equal validity" (Watson 1963, 163).

$L i$ er derfor i Xunzis fortolkning det fundamentale 'stof', hvoraf det ideelle samfund opbygges. Ritualerne (li) er de sociale omgangsformer, men er også meget mere end dette, fordi ritualerne danner grundlag for moralske værdier, æstetiske standarder og 
kulturelle normer. ${ }^{19}$ I praksis influerer ritualerne på de økonomiske transaktioner, politiske beslutninger og alle interpersonelle relationer. Dette er årsagen til, at alle må lære ritualerne i henhold til deres sociale position, hvilket samtidig betragtes som en realisering af mennesket og menneskeheden. Samtidig må vi ikke miste den horisont, der altid har været i kongfuzianismen, nemlig at uddannelse blev forstået som mere end blot et redskab for at skærpe en intellektuel forståelse. I kongfuzianismens forståelse af menneskelivet er mennesker vitalt forbundet med hinanden og endemisk med hele samfundet. Mennesket er i den henseende ikke blot et individ, men et medlem af familien og samfundet - en bidragsyder til civilisationen og en borger i kosmos. Da kongfuzianerne viede dem selv til studier af ritualerne og deres praksis, mente de, at de deltog i særlige moralske sandheder og praktiserede civilisationens fine kunst.

\section{LITTERATUR}

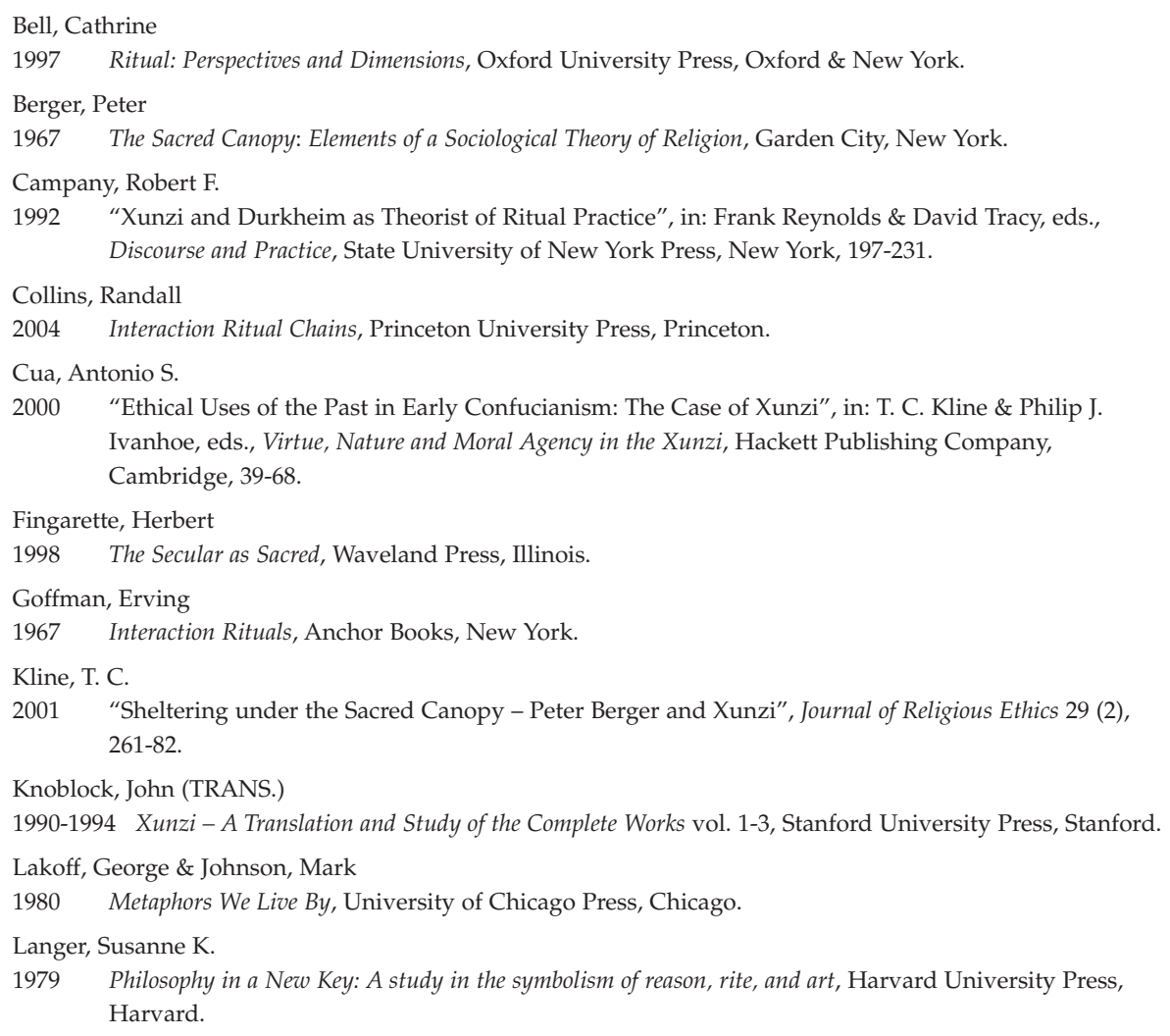

19 Fingarette formulerer det således: "The $l i$ are not simply established patterns and customary behaviour which shape people in a crudely behaviouristic fashion. They are sacred, 'concrete acts of human intercourse' which have the power to shape and humanize those who participate in them by dint of their 'magical' quality" (Fingarette 1998, 7). 


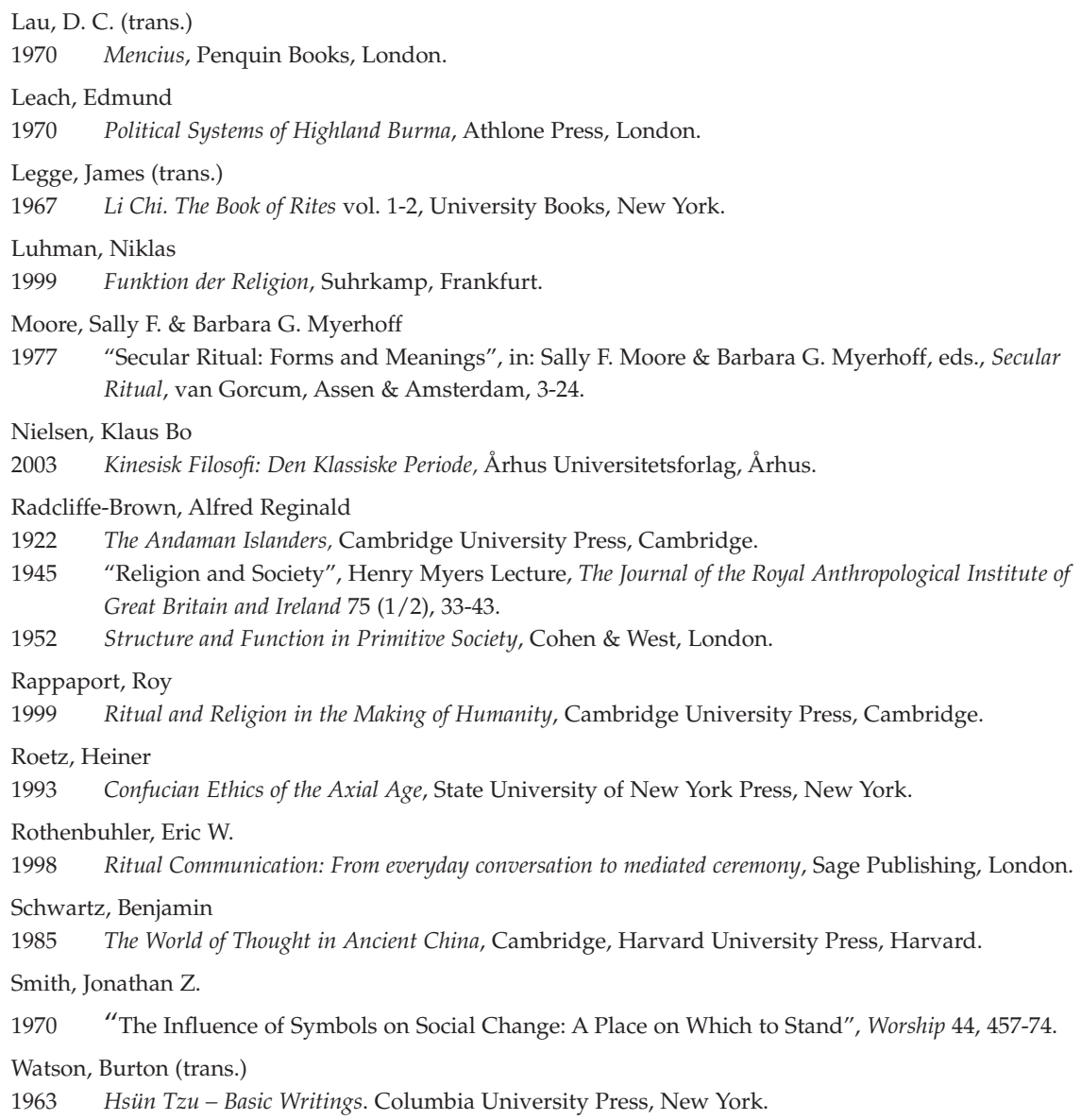

Klaus Bo Nielsen, projektmedarbejder, cand.mag. Afdeling for Religionsvidenskab, Aarhus Universitet 